\title{
マイクロシミュレーションとランダム効用モデルを応用した 世帯のライフサイクル-住宅立地一人口属性構成予測モデル
}

\section{A MODEL FOR ZONAL FORECAST OF LIFE CYCLE PROGRESS, RESIDENTIAL LOCATION AND POPULATION ATTRIBUTES USING RANDOM UTILITY MODELS AND A MICRO-SIMULATION TECHNIQUE}

\author{
林良嗣*・冨田安夫** \\ By Yoshitsugu HAYASHI and Yasuo TOMITA
}

\begin{abstract}
This study is an attempt to develop a forecasting method of population attributes by zone in a metropolitan area. Random utility models are used to formulate each event of household related to individual's life cycle and residential relocations. As the forecasting method, a micro-simulation technique, which can chase individuals' behaviours and can provide flexible aggregation, is employed. The validity test and policy tests proved the advantages of the model, compared with existing models.
\end{abstract}

Keywords : life cycle, residential location, micro simulation, random utility model

\section{1.はじめに}

この 10 年来，わが国における土地利用・交通分析の 分野では，特に住宅立地を中心として，欧米で開発され てきたモデルとは異なった独自のモデルが開発され，地 価をはじめとするわが国特有の局地的な土地条件に支配 された土地利用および人口等の分布の形成をかなりの精 度で表現できるようになってきた ${ }^{1) \sim 6)}$. また,一方で は，土地利用分析および交通分析の双方において，個人 あるいは世帯の行動に基づいた，いわゆる非集計行動モ デルの開発も進められてきており, 特に交通手段選択や 住宅タイプの選択等に関しては，集計的分析では十分に 扱えないような現象を巧みに表現できることが示されて きた ${ }^{7)-9)}$.

こうしたモデルは, 従来における現象の記述の段階か ら，最近では実際の交通施設計画等における効果予測分 析や，他の都市施設の整備計画への情報提供という応用 の段階に差しかかっているといえる. たとえば, 郊外鉄 道整備の自治体への影響分析においては, どのような年

* 正会員 工博 名古屋大学助教授 工学部土木工学科 ( ₹464 名古屋市千種区不老町)

** 正会員 工修 (財)計量計画研究所研究員 （１62 新宿区市ヶ谷本村町 2-9）
秢層の人口が増えるかによって，小学校あるいは老人 ホームといった施設需要が異なることから, その財政へ の影響も違ったものとなる．このように，人口の量的な 空間分布のみでは実際の施設計画に役立つ情報としては 不十分なことが多い. また一方で，こうした人口の属性 に応じた交通や立地の行動の違いを表現しようとしたの が非集計行動モデルであるが，これを将来予測に応用す るためには, その入力情報として, 将来の地区ごとの人 口属性構成が必要となる.

以上に述べたように, 将来の地区別の人口属性構成の 情報に対する要求は強くなってきている. しかし，これ を求める方法についての研究は, 従来, ごく少数に限ら れている. その中で, たとえば, 非集計行動モデルのた めの入力変数としての将来の地区別世帯属性構成を, そ れが現在と同様のパターンであるとの仮定の下に推計す る方法が提案されている ${ }^{10)}$. この種の方法は, 人口の移 動が微少な地区には適用可能であるが, 新しい交通施設 の整備された地区など立地移動の多い地区には適用が困 難であり，適用範囲が限定される.

そこで, 本研究では, 都市圏内の各地区ごとの人口属 性構成を一般的に表現するモデルの構築を試みるもので ある. 地区の人口属性構成の変化は, 出生, 就学・就職, 結婚, 死亡等による個人自身のライフサイクルにかかわ 
る属性変化と，世帯の立地移動との両方に起因して生じ る.これらおのおのの事象のモデル化には，ランダム効 用モデルを応用するが，予測方法としては従来の非集計 分析とは異なった方法として，本分析にとって種々の利 点をもたらすマイクロシミュレーションを応用した方法 を用いる。

\section{2. モデルの全体構成および予測方法}

\section{（1）モデルの全体構成}

図一1 は，モデルの全体構成を示したものである．住 宅需要は，世帯の意志決定により生じるものであり，ま ず世帯の意志決定の原因となる世帯のライフサイクル変 化をモデル化し，次いでその変化によって生じる住み替 え需要の顕在化を表現する，さらに，住み替え先の立地 が，各地区で得られる立地余剩 ${ }^{3}$ の大きさと，選択肢と して認識される住宅供給量の大きさに基づいて決定され る. 立地の進行によって, 地価が上昇し立地余剩が減少 することから，しだいに立地が抑制され，やがて均衡状 態に近づく。一方，住宅供給量は，住み替えによって生 じた空き家と，新規住宅供給量により与えられる.

以上がモデルの全体構成であるが，モデルの外生変数 としては，地価モデルに対して地区ごとの交通改善など の土地条件変化, また, 住宅需要の顕在化および住宅夕 イプ選択モデルに対して金融条件（住宅ローン金利）, さらに，住宅需要・立地モデルに対して大規模住宅団地 等の地区別の建設計画などが新規供給量として与えられ る.これ以外に，所得や地価の上昇等の変化を外生的に 与えることも可能である.

以上により, 種々の経済・社会環境の変化および政策

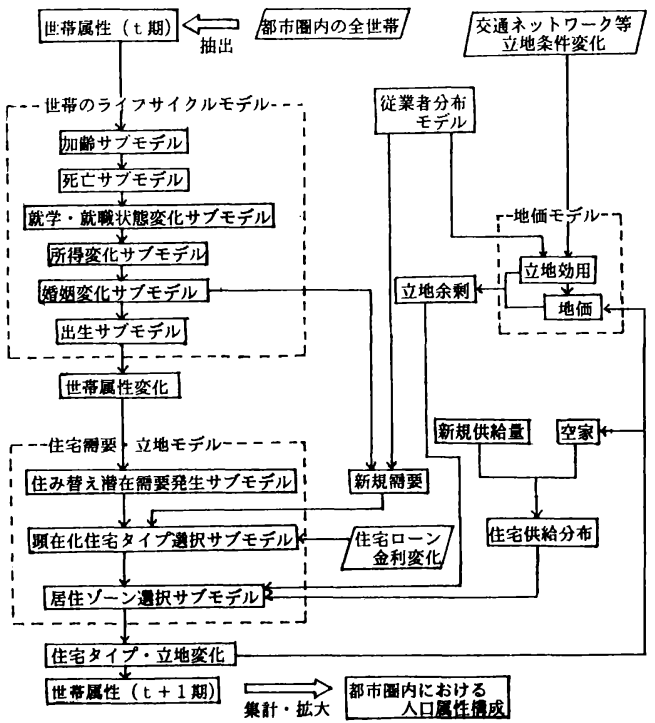

図一1 モデルの全体構成
が，都市圈内各地区の住宅立地および人口属性構成に及 ぼす影響を予測分析することができる.

\section{（2）予測方法}

a) 非集計行動モデルを用いた予測上の問題点

本研究においては，個人・世帯の行動に関する意思決 定行動を明示的にモデル化でき，かつ，多くの政策変数 を容易に内生化できることから，非集計行動モデルを中 心としたモデル構築を行っている.

しかし，非集計行動モデルを予測分析に適用するため には，その入力データとなる個人・世帯属性の将来値を 与えることが必要となるが，従来は，このための方法が ないことから短期予測に限定されていた。

そこで, 本研究においては，モデルの全体構成におい て述べたように，個人・世帯属性変化自体をもモデルに 内生化している，内性化にあたっては，多くの属性を扱 い，かつ，ダイナミックなモデル化が必要であることか ら，従来より非集計行動モデルの予測方法として用いら れているような平均值法や分類法 ${ }^{11), 12)}$ では限界がある. また，従来の方法の場合には予測結果に集計バイアス ${ }^{13)}$ が生じる等の問題が残されている.

b) マイクロシミュレーションとその適用例

以上の問題点を踏まえて, 本研究においてはマイクロ シミュレーションによる予測方法を採用する。 マイクロ シミュレーションとは, 最小分析単位である個人・世帯 など個々の行動主体を分析単位としたシミュレーション のことである．そのシミュレーション技法としては，個 人の行動を確率的に扱うことが必要であることからモン テカルロシミュレーションを用い，また，データの保存 方法としては，個人・世帯のデー夕をそのままリストと して保存する方法 (List-Processing) を用いる ${ }^{14)}$.

以上のようなマイクロシミュレーションの方法は，そ

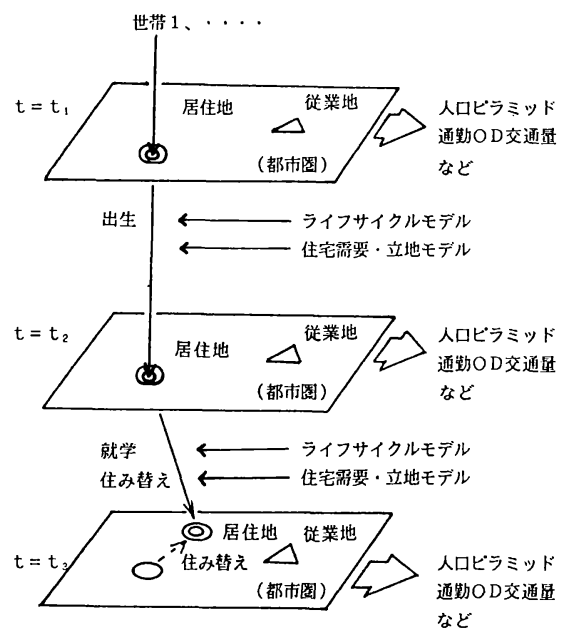

図一2 マイクロシミュレーションの概念図 
の応用の初期段階では人口統計学 ${ }^{15)}$ の分野で用いられ, 最近においては交通分析および土地利用分析への応用も 試みられるようになってきている.たとえば, Wegener ${ }^{16)}$ は住宅市場における需給の調整過程に, Bonsall'17) はカープールの分析にマイクロシミュレー ションを適用している.

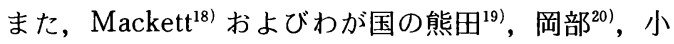
栗 ${ }^{21)}$ にって住宅立地モデルにも応用されているが, Mackettでは世帯の住み替えおよび立地行動は規範的に 与えられているにすぎず, さらに，日本のモデルでは世 帯のライフサイクル等の考慮もなされていない.

c) 本研究の予測方法

本研究においてはマイクロシミュレーションを用いて 以下のように予測する．たとえば，図一2は，その予測 方法を概念的に示したものである. 都市圈より分析に必 要な数の世帯を抽出し, それぞれの世帯についてライフ サイクルモデルおよび住宅需要・立地モデルによって, 世帯の時間的な変化を追跡する. 図一2では, ある世帯 が, $t=t_{1}$ から $t=t_{2}$ の間に子供を出生し, $t=t_{2}$ から $t=t_{3}$ の間に子供が成長し就学し, その結果として, 世 帯と住宅との不適合の増大から新たな居住地へ住み替え たという結果を示している．このように個々の世帯単位 の変化を追跡していく方法がマイクロシミュレーション である.なお，各世帯のデータは表一1に示すような属 性について個人・世帯属性りストとして保存されてお り，各世帯のシミュレーションの結果を各時点ごとに集 計することにより人口ピラミッドや通勤 OD 交通量な どが得られる.

d）本方法の特徴

本方法は, 以上のようなマイクロシミュレーションを 用いることによって次のような特徴を有している.

1）モデルの出力情報である人口ピラミッドおよび通 勤 OD 交通量を任意の時点で, 任意の人口属性グルー プ単位および空間単位で集計できる.

2) 個人の行動モデルを組み込んだ予測方法として適 しており, 従来, 交通および土地利用の分野で開発され てきている非集計行動モデルを有効に活用できる．その ため外的条件の変化に対して感度がよい22).

3）従来の非集計行動モデルの集計化方法として主に 用いられている平均值法, 分類法に比べて, モデル変数 としてかなり多くの属性を組み込んでも集計化が容易で

表一1 個人・世帯属性リスト項目

\begin{tabular}{c|l}
\hline 世帯 属性 & 世帯人員, 夫婦の組数 \\
\hline 個人属性 & $\begin{array}{l}\text { 年齢, 性別, 就学・就職状態, } \\
\text { 従業地, 年収, 婚姻状態 }\end{array}$ \\
\hline 住 宅 属 性 & $\begin{array}{l}\text { 居住地, 住宅の建て方, 所有形態, } \\
\text { 地価, 家貢・住宅ローン, 住宅の広さ }\end{array}$ \\
\hline
\end{tabular}

ある。

4）個人デー夕を集計せずにそのまま用いるので，集 計することによる情報の損失がなく，集計バイアスも軽 減される. また, データの効率的な保存も可能であ る注1).

\section{3. 世帯のライフサイクルモデル233}

\section{（1）考え方および定式化}

世帯の属性には種々のものがあるが, 本研究では, 住 宅需要発生および住宅立地に影響を及ぼす属性，すなわ ち世帯主年齢, 世帯人員, 世帯構成員の年齢構成, 所得 について, その将来変化を期を追って疑似動学的に予測 する. そのために世帯のライフサイクルモデルを, (1)加 歯, (2)死亡, (3)就学・就職, (4)所得変化, (5)婚姻状態変 化, (6)出生の 6 つのサブモデルより構成する.

各サブモデルの順序としては，まず，加㱓サブモデル により期初において年齢を更新する. 次に，個人が死亡 する場合には，他の属性の変化を予測する必要がなくな るため，まず，死亡サブモデルにより生死を判定し，そ の後に一般的な個人のライフサイクルの因果関係に従っ $\tau$, 就学 - 就職, 所得変化, 婚姻状態変化, 出生の各サ ブモデルの順にシミュレーションを行う.

ここで，上記(1) (6)の個人の各事象に対して，その生 起確率を求める方法を考える. 生起確率は, 年齢等の個 人属性のみならず, 時代によっても変化していくもので あり，たとえば，死亡率は，性別，年齢等の個人属性は もちろんであるが，医学の進歩等のために時代の推移に よっても変化していく. また, 婚姻率についても, 性別, 年齢のみならず，時代によっても変化する.

そこで, 本研究では, 個人属性および時代という要因 が，事象の生起確率に及ぼす影響は互いに独立であると 仮定して，これらの生起確率を次式のロジットモデルに より定式化する.

$$
\begin{array}{r}
\ln \left\{P_{i j} /\left(1-P_{i j}\right)\right\}=\mu+\mu_{i}^{A}+\mu_{j}^{P} \\
\sum_{i} \mu_{i}^{A}=1, \sum_{j} \mu_{j}^{P}=1 \cdots \cdots \cdots \cdots
\end{array}
$$

ここで, $P_{i j}$ : 属性 $i$, 時代 $j$ に対する事象の生起確率, $\mu$ : 定数, $\mu_{i}^{A}$ : 属性 $i$ のパラメーター, $\mu_{j}^{P}$ : 時代 $j$ のパ

注 1）たとえば，分類法を用いるために個人を夕イプ別に集 計したデータを保存する場合を考えよう.タイプ分類の ための属性項目数を $n$ 個, 属性項目 $i$ のカテゴリ一数を $l_{l}$ とすると, クロスの属性データ量(総夕イプ数)として は $\prod_{i=1}^{n} l_{i}$ となる. 一方, 個人データリストの場合, 属性 項目数を $n$, 個人数を $Q$ とすると, デー夕量としては $n Q$ である.これより，属性項目数 $n$ およびカテゴリー 数 $l_{i}$ が多数の場合には, $\prod_{i=1}^{n} l_{l}>n Q$ となり, 個人デー夕 リストによる方が効率的である.

たとえば, $Q=5000, n=10, l_{i}$ の平均值 $=5$ とすると, $\prod_{l=1}^{n} l_{l}=5^{10}=9765625 \gg n Q=50000$ となる. 
ラメーター

以上のように算定される事象の生起確率 $\left(P_{i j}\right)$ をもと にして，モンテカルロシミュレーションを用いて個人の 属性変化を追跡する. 図一3 は, 一例として婚姻状態変 化サブモデルのフローを示したものである．個人の属性 (年齢, 性別, 時代) に応じて式（1）により婚姻率を 求め,これと 0 から 1 の一様乱数とを比較し, 結婚する か否かを決定する．結婚する場合には，これが新規住宅 需要となるか否かを決定するために，世帯の独立確率を もとに独立か同居かが決定されることとなる.

出生, 死亡, 就学・就職の各サブモデルも同様なモデ ル化を行っている．また所得サブモデルでは年齢階層別 の所得の平均值および分散をもとにモンテカルロシミュ レーションにより世帯の所得を決定している.

なお, 世帯人員の変化は, 以上の各事象の結果として 表現され，世帯構成員の年齢は期初での年秢に経過年数 を加秢することにより与えられる.

\section{(2)推定結果}

6つの各事象ごとに，昭和 30〜55 年の国勢調査およ び人口動態調査の全国值などのデータを用いて, 式 ( 1 ) のロジットモデルを最尤推定法により推定する．昭和 55 年時点での実績值と推定值の相関関係により, 推定 結果の適合度をみると, どの推定結果も相関係数が 0.98 以上であり, 良好な結果が得られている.

ここで, 推定結果の一例として, 男子婚姻率の推定結 果を図一 4 および 5 に示す. 図一 4 の年齢パラメーター の推定值をみると，25才から 35 才において最も大きな 值を示しており，この年秢において最も結婚しやすいこ とを示している. また, 図一5に示す時代パラメーター の推定值をみると, 昭和 45 年以降パラメータ一值は低 下しており，同一年齢の婚姻率が時間経過とともに低下 していくことを示している. 次に, 昭和 55 年から昭和 60 年を予測することによりモデルの予測能力をみると, 図一6に示すように相関係数は 0.998 であり，きわめて 良好な結果であるといえる。

\section{4. 住宅需要・立地モデル24)}

\section{（1）モデル化の基本的考え方}

本研究では, 個人・世帯を追跡するマイクロシミュ レーションを用いることを前提としていることから，住 宅需要の発生および立地のモデル化には非集計行動モデ ルを用いることとする.

住宅需要に関する従来の研究としては, 住宅タイプご との需要推計に関して, 山田 ${ }^{25)}$, 宮本・宮地 ${ }^{26)}$, 林・磯 部・富田 ${ }^{27)}$, 枝村・川井・橋本 ${ }^{28)}$, $\mathrm{Anas}^{29)}$ らがあり, Wrigley and Longley ${ }^{30)}$, 宮本・安藤・清水 ${ }^{10)}$ は, それ らの中でも総括的な論文であるとみられる，また，最近

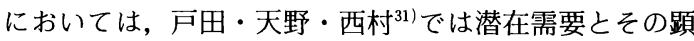
在化を区別しており，同一モデル構造ながらパラメ一 ターを違えるといった考慮も加えられている.

また, 立地に関する研究としては, 上記の研究におい ても, 都心, 近郊, 郊外といった程度の概略的な立地選 択については定式化されているが, 林・富田 ${ }^{32}$ は, 世帯 にとっての住宅供給量の認知の程度を考慮することによ り,ゾーン単位での詳細な立地選択をモデル化している. また, Anas $^{29)}$, 森杉・大野 ${ }^{33)}$ では, 地代, 地価を内生化 している.

これらの成果を踏まえて, 本研究では, 住宅の潜在需 要の発生段階から, 顕在化, 立地選択にいたる一連の過

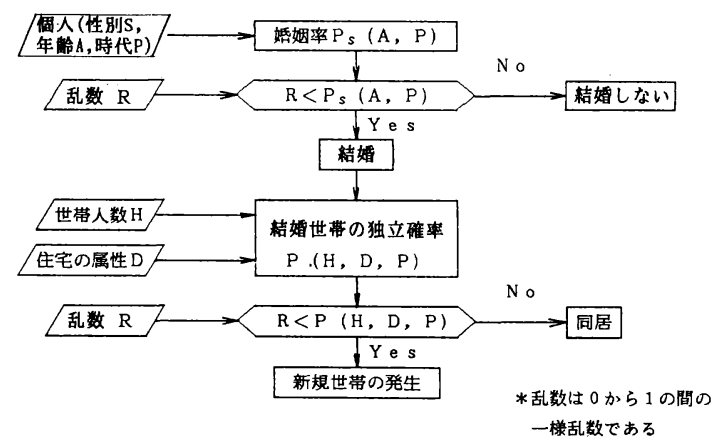

図一3婚姻状態変化サブモデル

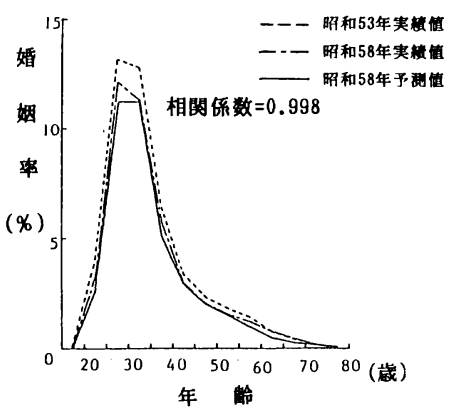

図一5男子婚姻率の時代パラメーター

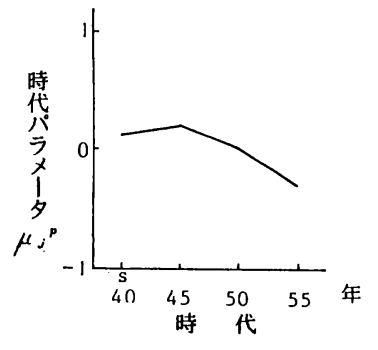

図一4 男子婚姻率の年齡パラメーター

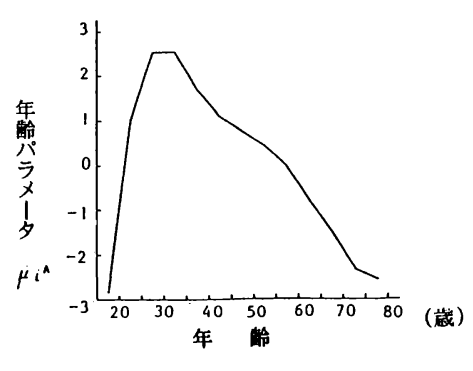

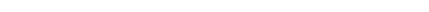


程を非集計行動モデルにより統一的に表現することを試 みるものであり,これは従来のモデルにない特幑である といえる.

住み替えに関する意志決定のモデル化にあたって，住 み替えの意志決定プロセスを，図一7に示すように，住 み替え潜在需要の発生と, 住み替え需要の顕在化の 2 段 階に整理し，世帯の住み替え行動をモデル化する．住み 替え潜在需要の発生段階 (Step 1) とは, 前節において モデル化されている世帯のライフステージの進行によ り，世帯の属性と住宅ストックの間に不適合が生じ，そ の結果, その世帯が住宅を探索しようとする段階である. また，住み替え需要の顕在化の段階（Step 2) とは，世 帯が，新たなライフステージに適合し経済的に負担可能 な住宅タイプ (広さ，価格，家貨なざ）および居住ゾー ンを見出すことによって，住み替え需要が顕在化する段 階である。

\section{（2）住み替え潜在需要発生モデル（Step 1)}

本モデルは, 住み替え潜在需要を現在の居住住宅に不 満足な世帯であると定義し，この不満足な世帯の発生量 を与えるものである。ここで，不満足な世帯は現在の住 宅より効用の高い住宅が見出されれば，住み替えを希望 する世帯であり，一方，満足な世帯とは，このような住 宅の存在にかかわらず住み替えの意志のない世帯であ る.この両者を区別することにより，いわゆる選択層と 非選択層を分離することができ，より予測精度の高いモ デルが期待できる. また, 不満足な世帯の総量を把握し ておくことは住宅政策の評価のうえでも有効な情報であ ると考えられる.

いま, 世帯 $h$ は, 居住住宅 $d$ に対する効用 $U_{h d}$ によっ て, 満足あるいは不満足を判断しているものと仮定する. そして, この不満足である確率 $P$ を次式のように非集 計ロジットモデルによって定式化する.

$$
P=1 /\left\{1+\exp \left(V_{h d}\right)\right\}
$$

ここで, $V_{h d}$ は $U_{h d}$ のうち観測可能な変数により説明さ れる部分である. 観測可能な効用 $V_{h d}$ の説明変数とし ては, 世帯のライフステージを表わす世帯属性変数およ び住宅属性変数を用いる.

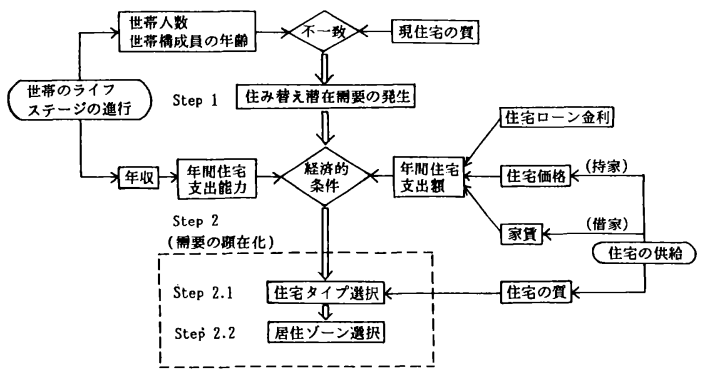

图一7 住宅需要・立地モデルの考え方
（3）需要の顕在化,住宅タイプ選択,および居住ゾー ン選択モデル (Step 2)

以下のモデルによって, 住み替え潜在需要が顕在化す るか否か，また，顕在化するとすれば，દ゙の住宅タイプ および居住ゾーンを選択するかが順次決定される。これ らの世帯の意志決定は相互依存的な関係にあり，これを モデル化するためにネスティドロジットモデルを用いて いる.

a）需要の顕在化および住宅タイプ選択モデル

4. ( 2 ) のモデルょり求められる住み替え潜在需要世 帯は, 住み替え先の住宅夕イプ $d$ の効用 $U_{d}$ が, 現在の 住宅の効用 $U_{d_{0}}$ に比べて，ある一定值（移転抵抗）より 大きい場合に住み替えが顕在化するものと仮定する。こ れを，非集計ロジットモデルにより定式化すると，住み 替えの顕在化しない確率 $P_{0}$, あるいは, 住宅夕イプ $d$ を選択する確率 $P_{d}$ は次式で表わされる.

$$
P_{d}=\exp \left(V_{d}\right) / \sum_{d=0}^{n} \exp \left(V_{d}\right) \quad(d=0,1, \cdots, n) \cdots
$$

ここで, $V_{d}: U_{d}$ のうち観測可能な変数により説明され る部分

$n:$ 住宅タイプの数

住み替え需要の顕在化においては，特に経済的な制約 が重要であり，本研究では，世帯にとっての住宅支払の 難易度を, 世帯の住宅支出能力に対する年間住宅支出額 の割合として指標化する．年間住宅支出額としては，借 家の場合は年間家梖を，持家の場合は次式により得られ る年間返済額 $r$ を用いる.

$$
\left.r=\left(c-c_{0}\right)\left\{i(1+i)^{T}\right\} /(1+i)^{T}-1\right\} \cdots
$$

すなわち, 年間返済額 $r$ は, 住宅ローン金利 $i$ のも とで，住宅価格 $c$ から自己資金 $c_{0}$ を差し引いた金額を $T$ 年間で均等返済するものとして求めた金額とする. 自己資金 $c_{0}$ の中には貯蓄額, 現有物件の処分額, 臨時 の入金等が含まれる．また，年間住宅支出能力は所得ラ ンクごとの年間平均住宅支出額を用いる.

b）居住ゾーン選択モデル

世帯は，居住ゾーンの選択にあたって，次のような規 範に従うものと仮定する.

(1) 世帯は可能な限り立地効用が大きく，立地費用の 小さい居住ゾーン，すなわち立地余剩 ${ }^{3)}$ (=立地効 用一地価）が最も大きいゾーンを選択する.

(2) 立地余剩に差がない場合は，供給される住宅戸数 の多いゾーンほぼ選択されやすい.

(3) さらに，この供給量は，現居住地から遠くなるに 従って，世帯がそれを認知する確率が低下する.

以上の選択行動規範を非集計ロジットモデルにより定 式化すると，次式のようになる. 
$P_{J t_{0} i}=A_{i_{0}} \cdot \exp \left(\gamma X_{j i}\right) / \sum_{i=1}^{n} A_{i_{0} i} \cdot \exp \left(\gamma X_{j i}\right)$

ここで,

$P_{J_{i 0} i}$ : 従業ゾーン $j$, 現居住ゾーン $i_{0}$ の世帯が, 新 居住ゾーン $i$ を選択する確率

$X_{j l}$ : 従業ゾーン $j$ に通勤する世帯主をもつ世帯に とっての新居住ゾーン $i$ に対する立地余剩

$A_{i 0 i}$ ：居住ゾーンにおける住宅の供給量のうち, 選択 肢として認知される量（選択肢の大きさ）

なお，選択肢に対する認知の程度は現居住ゾーンから の時間距離により逓減するものと仮定し， $A_{i_{00}}$ を次式で 表わす.

$A_{i_{0} i}=\left(S_{i}\right)^{\alpha} \cdot \exp \left(\beta t_{i_{0} i}\right)$

ここで,

$S_{i}:$ 新居住ゾーン $i$ における住宅供給量

$t_{i_{0} i}$ : 現居住ゾーン $i_{0}$ から新居住ゾーン $i$ までの時 間距離

なお，立地余剩は，5．の地価モデルにより計算される．

\section{(4) 推定結果}

以上の住宅需要・立地サブモデルを，図一8 に示す名 古屋都市圈を対象地域として, 昭和 53 年住宅需要実態 調査のデー夕を用いて推定する。なお，対象地域を 14 のゾーンに分割しており,必要に応じて各ゾーンを都心， 近郊，郊外に区分している.

a) 住み替え潜在需要発生モデル

推定の結果, 表一2 のような結果が得られた. 変数の 符号条件, $t$ 值，的中率をみると，比較的良好な結果が 得られたといえる. パラメーターは値が小さいほど不満 足であることを表わしているが，推定結果は，他の条件 が同一ならば，世帯人員一人当たりの広さが狭いほど， 世帯主年齢が高いほよ゙，また，持家に比べて借家の方が 不満率が高いことなどを示している.

b）需要顕在化および住宅タイプ選択モデル

推定結果は, 表一 3 に示されるように, 変数の符号条 件, $t$ 值, 尤度比, 的中率をみると, 比較的良好な結果 が得られたといえる。パラメーターの值は，大きいほよ゙

表一2 潜在需要発生モデルの パラメーター推定結果

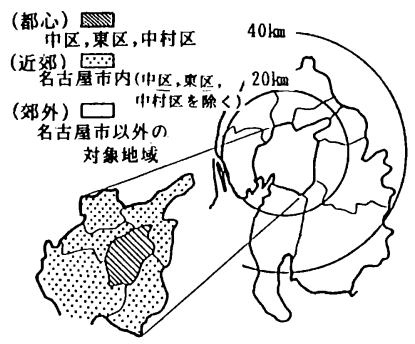

図一8 対象地域と地区区分
その選択肢を選びやすいことを表わしている.これより， 持家・戸建に居住している場合が最も移転抵抗が大き く，借家・中高層の場合が最も移転抵抗が小さいことを 示している. また，現居住場所の立地余剩が大きいほど 移転しにくく，一方，一人当たりの広さが大きく，また， 年間住宅支出能力に対して年間住宅支出額が小さい住宅 タイプほど選択されやすいことを意味している.

c) 居住ゾーン選択モデル

希望する住宅夕イプによって居住ゾーンの選択特性が 異なると考えられることから，住宅夕イプ別にモデルを 推定した。なお，モデル構造としては，図一8に示す 14 ゾーンの同時選択モデルとなっている．また，内々所要 時間としては，各ゾーンに含まれる市区町村間の所要時 間と，市区町村内々の所要時間（パーソントリップデー 夕による) を，住み替え件数で重みづけ平均した值を用 いている.

推定結果は表一 4 に示すように, 移転前後のゾーンペ アの的中率としては $41 \%$ ～57\% と十分に高いとはいえ ないが, 移転後のゾーン別立地量の相関係数でみると, 0. 82 0.90 と比較的高い值が得られている.

立地余剩 $\left(X_{j i}\right)$ の係数をみると, 借家モデル (model-3, model-4) に比べて，持家モデル (model-1, model-2) の方が大きな值となっている。これは，立地余剩という 指標が地価負担を反映したものであるのに対し，借家に とっての負担は地代（家顀）であり，それは地価に比し てゾーン間較差が小さいため，立地余剩による説明力が 比較的小さいと考えられる．また，住み替え前後の居住 地の時間距離 $\left(t_{i_{0}}\right)$ は，いずれのモデルでも最も有意な 変数であり，その係数をみると, model-4 の係数が最も 大きく，借家・中高層を選ぶ世帯では，現居住地の近く に移転する傾向が比較的強いことを示している.
表一3 需要の顕在化・住宅タイプ選択モデルの パラメーター推定結果

\begin{tabular}{|c|c|c|c|}
\hline \multicolumn{2}{|c|}{ 説明変数 } & 現住宅タイプ & 移転先住宅タイプ \\
\hline \multicolumn{2}{|c|}{$\frac{\text { 㕕さ (畳数) }}{\text { 世帯人数 }}$} & \multicolumn{2}{|c|}{$0.03(2.01)$} \\
\hline \multicolumn{2}{|c|}{$\begin{array}{l}\text { 年間住宅支出韻 } \\
\text { 年閒住宅支出能力 }\end{array}$} & - & $-0.68(4.50)$ \\
\hline \multicolumn{2}{|c|}{$\begin{array}{c}\text { 現居住任宅の } \\
\text { 立地余剩 }\end{array}$} & $0.96(4.72)$ & - \\
\hline \multirow{4}{*}{$\begin{array}{l}\text { 移 } \\
\text { 転 } \\
\text { 抵 } \\
\text { 抗 }\end{array}$} & 持家・戸建 & $9.17(12.75)$ & $=$ \\
\hline & 持家·中高層 & $6.98(7.80)$ & $=$ \\
\hline & 借家・可建 & $7.40(10.33)$ & - \\
\hline & 借家·中高畐 & $6.25(8.77)$ & - \\
\hline \multirow{4}{*}{$\begin{array}{l}\log - \\
\text { sum } \\
\text { 変数 }\end{array}$} & 持家・厄建 & - & $0.60(4.17)$ \\
\hline & 持家 - 中高層 & - & $0.82(2.29)$ \\
\hline & 借家・戸建 & 一 & $0.25(1.97)$ \\
\hline & 借家・中高層 & - & $0.46(2.83)$ \\
\hline \multicolumn{2}{|c|}{ 供給童 $\ln \mathrm{N}$} & - & $0.78(5.11)$ \\
\hline \multicolumn{2}{|c|}{ サンプル数 } & \multicolumn{2}{|r|}{1620} \\
\hline \multicolumn{2}{|c|}{ 尤度比 } & \multicolumn{2}{|c|}{0.47} \\
\hline \multicolumn{2}{|c|}{ 的中率 } & \multicolumn{2}{|c|}{$73 \%$} \\
\hline
\end{tabular}

( )内： $\mathrm{t}$ 值 
表一4 居住ゾーン選択モデルのパラメーター推定結果

\begin{tabular}{|c|c|c|c|c|}
\hline 説明変数 & $\begin{array}{c}\text { model-1 } \\
\text { 持家·六建 }\end{array}$ & $\begin{array}{c}\text { model-2 } \\
\text { 持家.中高層 }\end{array}$ & $\begin{array}{c}\text { model-3 } \\
\text { 借家·戸建 }\end{array}$ & $\begin{array}{c}\text { model-4 } \\
\text { 借家·中高首 }\end{array}$ \\
\hline $\ln \operatorname{si}(\alpha)$ & $0.41(3.40)$ & - & $0.30(2.29)$ & $0.41(2.03)$ \\
\hline $\operatorname{tio} \mathrm{i}(\beta)$ & $-0.04(14.3)$ & $-0.03(4.91)$ & $-0.03(7.44)$ & $-0.06(10.6)$ \\
\hline$\nabla \mathrm{ji}(\gamma)$ & $2.47(9.62)$ & $2.39(4.30)$ & $1.50(4.96)$ & $0.78(2.09)$ \\
\hline サンブル数 & 239 & 41 & 93 & 126 \\
\hline 尤度比 & 0.54 & 0.42 & 0.43 & 0.46 \\
\hline 的中事 & $57 X$ & $41 \%$ & $45 \%$ & $53 x$ \\
\hline 相関係数 & 0.90 & 0.84 & 0.82 & 0.88 \\
\hline
\end{tabular}

（）内： th值

5. 地価モデル

\section{(1) モデルの考え方}

地価モデルには，ランダム付け値モデル ${ }^{34)}$ を用いてい る.これによれば, 世帯主が従業地 $j$ へ通勤する世帯 の居住地 $i$ に提示する付け值を $b_{s l}$, その世帯数を $N_{s i}$ とすれば, 居住地 $i$ の地価は次式となる.

$$
P_{i}=(1 / \omega) \ln \sum_{j} \exp \left(\omega b_{s i}+\ln N_{j i}\right)
$$

ここで, $b_{j i}=\sum_{k} \alpha_{k} z_{k i}$

$\left(\alpha_{k}\right.$ : パラメー夕ー, $z_{k i}$ : 居住地 $i$ の $k$ 番目の土地条件 $)$ 以上により, 立地余剩は $X_{j i}=b_{j i}-P_{i}$ として求められ る.

なお, 付け值世帯数 $N_{j i}$ としては, 立地世帯数を用い ており，これにより立地の進行により地価が上昇する構 造となっている.

\section{(2) 推定結果}

以上の地価モデルを, 名古屋都市圈の昭和 55 年公示 地価データ 520 サンプルを用いて最尤推定法により推定 した結果を表一5に示す.

\section{6. モデルの検証と政策テスト}

\section{(1) モデルの検証}

以上で構築したモデルを用いて, 名古屋都市圈を対象 として, 昭和 53 年を基準年として昭和 58 年を事後的に 予測し, この予測結果と昭和 58 年の実績值とを比較す ることにより, モデルの検証を行う. 検証のためのデー 夕は, 昭和 58 年住宅需要実態調査を用いている.

a) 住み替え潜在需要および住宅タイプ別住み替え世

表一5＼cjkstart地価モデルのパラメーター

\begin{tabular}{|c|c|c|}
\hline \multicolumn{2}{|r|}{ 説明変数 } & 係数 \\
\hline$\alpha_{1}$ & 通勤一般化費用 & $\begin{array}{r}-1.49 \\
(-6.54)\end{array}$ \\
\hline$\alpha_{2}$ & 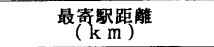 & $\begin{array}{l}-1.10 \\
(-4.06)\end{array}$ \\
\hline$\alpha_{3}$ & 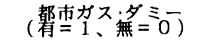 & $(7,50)$ \\
\hline$\alpha_{4}$ & $\begin{array}{l}\text { 下水道·多ミ無 } 0) \\
\end{array}$ & $\begin{array}{r}2.38 \\
(12.2) \\
\end{array}$ \\
\hline$\alpha_{5}$ & 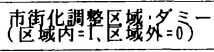 & $\begin{array}{r}-2,05 \\
(-5,39) \\
\end{array}$ \\
\hline$\omega$ & 分散バラメータ & $\begin{array}{l}0.542 \\
(24.8)\end{array}$ \\
\hline & 重相関係数 & 0.87 \\
\hline & サンブル数 & 520 \\
\hline
\end{tabular}

( )内: $\mathrm{t}$ 值
表一6 住み替え潜在需要・住宅タイプ別住み替え世帯数の実縝 值と予測値の比較

\begin{tabular}{|c|c|c|c|c|}
\hline & $\begin{array}{l}\text { 契績值 } \\
\text { (千世带) }\end{array}$ & $\begin{array}{l}\text { 予测做 } \\
\text { (千世带) }\end{array}$ & $\begin{array}{r}\text { 誤差無 } \\
(\%)\end{array}$ \\
\hline \multicolumn{2}{|c|}{ 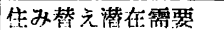 } & 767 & 789 & 2.9 \\
\hline \multirow{4}{*}{$\begin{array}{l}\text { 䫘要 } \\
\text { 在世 } \\
\text { 化带 } \\
\text { 需 }\end{array}$} & 持家・穴建 & 80 & 85 & 6.3 \\
\hline & 持家・中高層 & 28 & 22 & -21.4 \\
\hline & 借家・市建 & 32 & 33 & 3.1 \\
\hline & 借家 - 中高層 & 70 & 77 & 10.0 \\
\hline
\end{tabular}

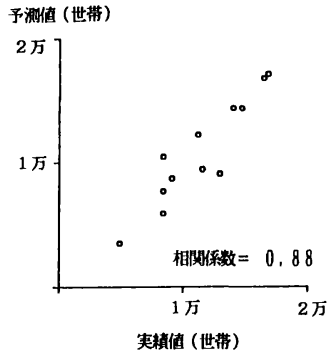

図-

\section{ゾーン別立地世帯数の 图一10 住み替え前後のゾーン 実績值と予測值の比較 \\ ペアごとの住み替え世 帯数の実績値と予測值 の比較}

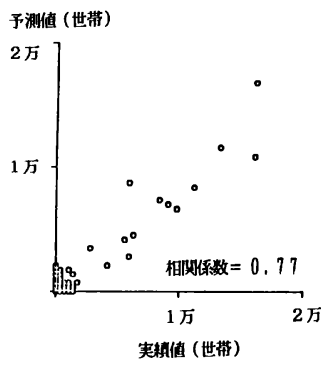

帯数の予測精度の検討

事後予測結果を誤差率で示したものが表一6であり, これより比較的良好な結果が得られたといえる.ただし， 持家・中高層についてはサンプル数の関係もあってやや 精度が落ちる。

b）住宅立地量および住み替えの空間パターンの予測 精度の検討

ゾーン別立地世帯数の予測値と実績值の相関係数は, 0.88 (図一9）という良好な結果が得られた。また，こ の立地世帯数を移転前後のゾーンペア別にみても，その 相関係数は 0.77 （図一10）であり比較的良好な結果で あるといえる.

このように移転前後のゾーンペア別にモデル精度を検 討した例は, 従来の研究ではみられなかったと思われる. これは, 従来のほとんどのモデルでは, 従業地からの距 離が同じゾーンならば，移転先として無差別となってい たために，従業地に対して現居住地と同じ方面に移転し やすいという現実の傾向をモデル化していなかったため であると考えられる. 以上の考慮により，本モデルでは， 住み替えによる通勤 OD 交通量の変化量を, かなり良 い精度で予測できるようになった。

c）人口属性構成の予測精度の検討

次に，世帯属性の 1 つである世帯主年齢について，そ の予測精度を検証した，図一11，図一12 は，都心地区お よび近郊地区から選ばれたゾーンでの予測值と実績值の 比較であり，相関係数はそれぞれ $0.96 ， 0.98$ という良 好な結果である. 両ゾーンとも世帯主年齢 50 才以上に 
おいて過大推計となっているが，これは退職等に伴う世 帯主の移行が, データの制約のため考慮されていないこ とによると考えられる. なお，他のゾーンにおいても同 程度の予測精度が得られている。

(2) 政策テスト

本モデルは，6. でまとめるように，かなりの種類の 政策や社会・経済環境の変化の効果影響を分析すること ができるように設計されている．ここでは，そのいくつ かの典型的な例について名古屋都市圏を対象に政策テス 卜を行った結果を示す。なお，以下の政策テストは次の 設定条件に基づくものである.

(1) シミュレーションの基準年は, 昭和 53 年とする.

(2) 経年的分析は, 5 年ごとの疑似動学的（繰り返し） シミュレーションによる.

(3) 都市圈内と外での人口移動はないものと仮定す る. したがって本分析では, 都市圏内の居住者のラ イフサイクルの進行の影響および都市圏内での住み 替えの影響をみていることとなる。

(4) 都市圈内の新規住宅供給量の総量は需要に対して 弾力的に与えられるものとする.

a) 世帯のライフサイクルの進行の影響

i）年㢼構成の推移

高齢化の進展によって, 将来の人口構成に占める高齢
者の割合は増加するものと予想される。これを本モデル を用いて, ゾーン別に昭和 53 年から昭和 73 年まで予測 した結果を図一13に示す。これによれば，都心地区の ゾーンでは急激に高齢化が進行し, 近郊地区および郊外 地区のゾーンでは高齢化は進行するものの, 都心地区に 比べればかなり緩やかであることがわかる．このように 高齿化問題は，都心地区の若い世帯が近郊・郊外地区へ 住み替えることから都市圈全体というよりも局地的に起 こってくるものであることが定量的に把握され，これは 都市政策上重要な情報ともなる.

ii ） 住宅タイプ別住宅需要量の推移

図一14に示すように, 都市圈全体の住宅需要量は昭 和 58 62 年にやや減少した後に徐々に増大しでいく傾 向にあり，これを住宅タイプ別にみると，持家・戸建の 需要量は他の夕イプに比べて増加傾向が顕著である.こ れは, 人口ピラミッドで最も多い人口の年軨階層の世代 （昭和 21 年 25 年生まれ）が, ライフステージの進行 とともにやがて所得も上昇し，持家・戸建を取得しやす い年齢層となるためであると考えられる.

b）経済環境変化の影響

i ）住宅ローン利子率の変化の影響

近年, 住宅ローン利子率が引き下げられ，住宅需要が 増大している.ここでは, 利子率の変化による住宅需要・ 立地への影響をモデルによって，どの程度とらえること

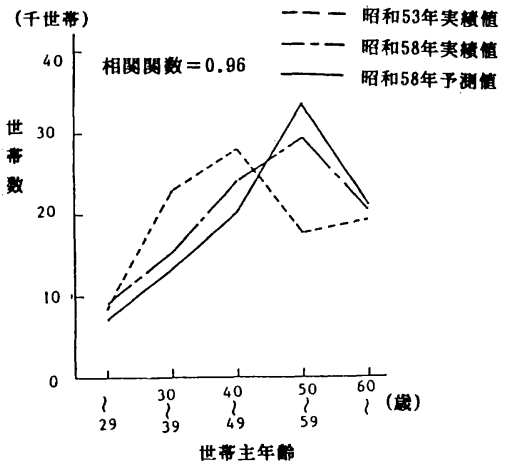

図一11 都心地区の世帯主年齡別世帯数の 予測值と実績值の比較

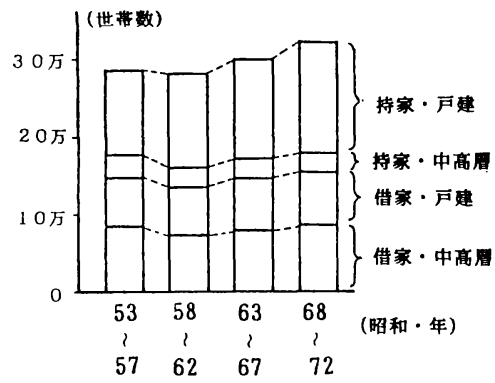

図一14 住宅タイプ別住み替え世帯数の 推移

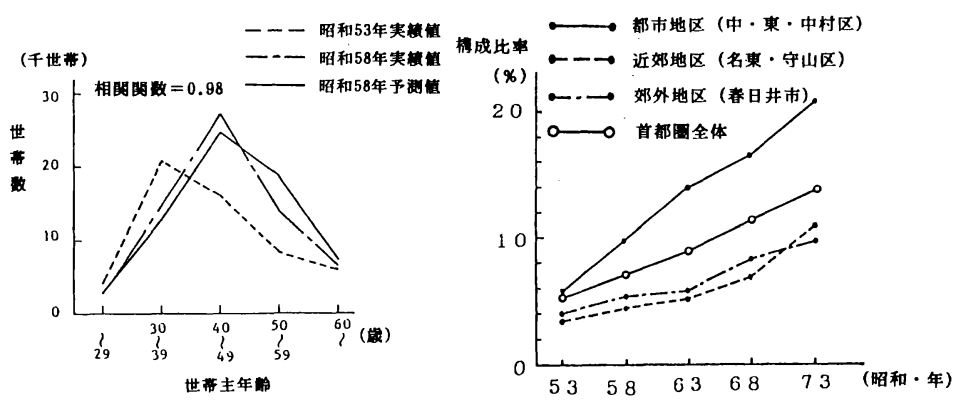

図一12 郊外地区の世帯主年齡別世帯数 の予測値と実䋶值の比較

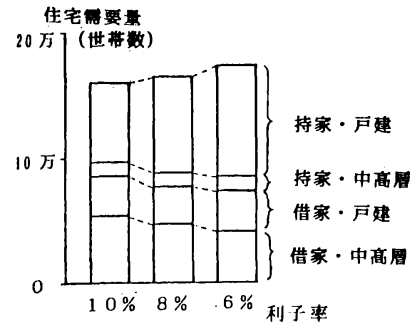

図一15 住宅ローン利子率の変化と住宅タ イプ別住宅需要量の関係

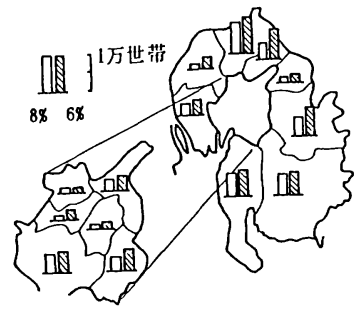

図一16 住宅ローン利子率の変化と 持家・戸建の地区別立地量 の関係 
ができるかについて考察する.

たとえば, 利子率を $10 \%$ から $4 \%$ まで $2 \%$ ごと低 下させて, 住み替え世帯を住み替え後の住宅タイプ別に みてみると，図一15,16のような結果が得られた。これ は, 利子率の低下に伴って, 年間住宅支出額が低下し, その結果, 住み替え世帯の総数が増大することを示して いる.これを，住宅タイプ別にみると，住宅ローン金利 に依存するのは持家であること，また，持家・戸建の住 宅の質が他のタイプと比べて高いことによって, 持家・ 戸建の需要量の増大が比較的䫓著となっている. 逆に, 借家・中高層の需要量は利子率の低下に伴って減少して いる，ただし，本テストでは，金利は供給側には影響し ないものとしている.

ii ）所得の変化の影響

所得上昇は, 年間住宅支出能力を増す。この例では, 住宅ローン利子率低下による年間住宅支出額の低下と同 様の効果が得られた。そこのため, 結果の詳細は省略する.

\section{c）土地条件の変化の影響}

土地条件として地価をとりあげ, 近年, 大都市圈等で 起こっている都心およびその周辺部での住宅地地価が上 昇する場合を想定する．ここでは，中心都市である名古 屋市域内において住宅地地佃が変化しない場合, および $10 \%$ 上昇する場合について, 住宅需要の現われ方につ いて検討した結果，図一17,18 のように都心および都心 周辺部の地価の上昇は, 全体の住宅需要量を減少させ, 一方では, 人口の郊外化を促進させる傾向を示した。

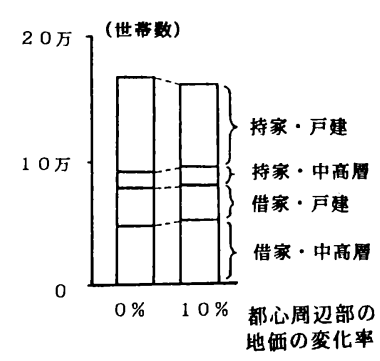

図-17 都心周辺部の地価の変化と住宅タイプ別住宅需要量の 関係

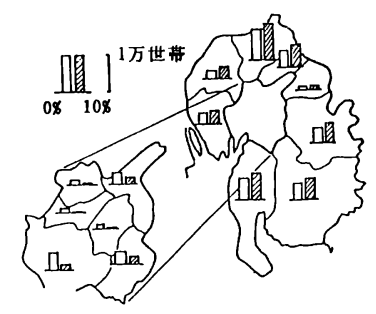

図一18 都心周辺部の地価の変化と持家・戸建の地区別立地量 の関係

\section{7. まとめ}

本研究では, 個人属性の変化および住宅立地に関する 意志決定を確率的にモデル化し, これらのモデルを用い た予測方法として，個人を追跡する方法であるマイクロ シミュレーションを用いることにより, 多くの個人属性 を考虑した将来予測分析をすることを可能にした，そし て, このモデルを名古屋都市圈へ適用した結果, 比較的 良好な再現性が得られることがわかった。この予測シ ミュレーションに必要な $\mathrm{CPU}$ 時間は, 名古屋大学大型 計算機センターの FACOM M-382 システムを用いた場 合, 5 年 1 期当たり 17 秒と比較的短い時間であった.

本研究におけるモデルの第 1 の特徵は, 非集計行動モ デルを応用して, 住み替え需要の発生から住宅夕イプ選 択, そして居住地選択に至るまでの世帯の意志決定を一 貫してモデル化したことである. 特に, 本研究における 特徵は, 潜在住宅需要と顕在化住宅需要を区別したこと, また, 現居住地からの距離に応じて住宅供給に対する認 知の程度が異なることを明示的に考慮したことによっ て, 住み替え先ゾーンの予測精度が向上し, 通勤 $\mathrm{OD}$ 交通量の変化分の予測精度が向上したことである.

第 2 の特徵は, 政策テストにおいても示したように, 交通施設整備等に伴う土地条件変化の影響分析のみなら ず,世帯のライフサイクルの進行や,住宅ローン利子率・ 所得・地価上昇等の経済環境の変化, あるいは住宅供給 政策等の影響分析が可能であり, 従来のモデルに比べて, かなり広範な政策分析が可能となったことである.

第 3 の特徵は, モデルの出力情報の詳細化・柔軟化で ある.すなわち, ゾーン別の人口の量のみならず, 転出・ 転入ゾーン別・属性別の住み替え世帯数・人口が比較的 精度よく得られた。 また, ゾーン別人口・世帯属性構成 とその推移（たとえばゾーン別年秢別人口の推移）が得 られた.この情報は, 地区ごとに老秢化が進行したり, 若年層が転入するといった傾向を定量的に示し得るもの であり,これに対応した都市基盤施設・住宅等を供給す るうえで有効なものである. また, これらの出力情報を, マイクロシミュレーションの長所により, 任意の時点, 任意の人口属性グループ単位および空間単位で集計して 示すことが可能であることも本モデルの大きな特徴であ る.

第 4 の特徵は, 本モデルにより, 交通および土地利用 の分野においてすでに開発されている多くの非集計行動 モデルに対して, 予測分析上必要不可欠な地区ごとの個 人属性デー夕の将来変化を与えることを可能としたこと である.これにより,これまで短期予測に限られていた 非集計行動モデルを用いた予測に対して, 中長期への適 用の可能性を高めた. 
最後に, 本研究を進めるに際しては, 名古屋大学の河 上省吾教授をはじめとする交通問題研究会のメンバー, および査読者の方々より貴重なコメントを頂戴した。ま た, 膨大な計算作業に対して, 大学院生の奥田隆明君, 小出和昭君の多大な協力を得, その過程で出された種々 の工夫がモデルに生かされている. 以上, ここに記して 深く感謝の意を表する.

\section{参考 文 献}

1）青山：土地利用モデルの歴史と概念, 土木学会論文集, 第 347 号 $/ \mathrm{IV}-1$, pp. 19 28, 1984.

2) Webster, F.V., et al. ed. : Urban Land-use and Transport Interaction-Policies and Models, Gower 1988.

3) 中村・林・宮本：都市近郊地域の土地利用モデル, 土木 学会論文報告集, 第 309 号, pp. 103 112, 1981.

4) 中村・林・宮本：広域都市圏土地利用交通分析システム, 土木学会論文報告集, 第 335 号, pp. 141 153, 1983.

5）阿部・天野・戸田：つけ值概念を用いた土地利用変動メ カニズムの考察とそのモデル化について, 土木計画学研 究発表会講演集, No.6, pp. 149 154, 1984.

6）天野・阿部：広域都市圈を対象とした活動立地モデルに 関する研究, 土木計画学研究 - 論文集, No. 2, pp. 165 172, 1985.

7) 屋井：非集計行動モデルとその実用性, 土木計画学研究・ 論文集, No. 3, pp. 23〜39, 1986.

8）原田：非集計行動モデルによる多次元選択行動の分析, 土木計画学研究・論文集, No. 4, pp. 15 27, 1986.

9）宮本：立地選択モデル, 非集計行動モデルの理論と実際, 土木計画学講習会テキスト, 土木学会編, pp. 161 174, 1984.

10）宮本・安藤・清水：非集計行動分析に基づく都市圏住宅 需要モデル, 土木学会論文集, 第 365 号, pp. 79 88, 1986.

11) Koppelman, F.S. : Prediction with Disaggregate Models : The Aggregation Issue, Transportation Research Record, Vol.527, pp. 73〜80, 1974.

12）森地：非集計行動モデルによる予測, 非集計行動モデル の理論と実際, 土木計画学講習会テキスト, 土木学会編, pp. $121 \sim 148,1984$.

13）桐越・浅野・塚本：非集計ロジットモデルの集計バイア スに関する研究, 土木計画学研究・論文集, No. 1, pp. 107〜114, 1984.

14) Clarke, M., et al. : Micro-Simulation, Quantitative Geography in Britain, pp. 248 256, 1982.

15) Orcutt, G. H., et al. : Microanalysis of Socioeconomic Systems, A Simulation Study, Harper and Brothers, New York, 1961.

16) Wegener, M. : A Multilevel Economic-Demographic Model for Dortmund Region, Sistemi Urbani, pp. 371 401, 1982.
17) Bonsall, P. : Microsimulation of mode choice : a model of organized car sharing, PTRC proceedings, 1979.

18) Mackett, R. : Forecasting the Long Term Effects of Increase in the Cost of Travel, Simposium on New Derections in Urban Modelling, 1983.

19）熊田ほか：住宅立地シミュレーションモデル，住宅， Vol.17, No. 11, pp. 22 35, 1968.

20）岡部：住宅立地・住宅地計画シミュレーションモデルお よびそれによる若干の考察, 住宅, Vol.20, No. 8, pp. 18〜36, 1971.

21）小栗：大都市圈住宅住み替えモデルにおける住宅・居住 地探索ルーチンの設計, 都市計画別冊, pp. 151 156, 1979.

22）柏谷：住宅立地シミュレーションモデル, 天野編「計量 都市計画」第 5 章, pp. 129 132, 1984.

23）林・富田・小出：世帯のライフサイクルに伴う属性変化 のモデル化の一方法, 第 42 回土木学会年次講演会概要集, pp. 486 487, 1987.

24）林・富田・奥田：住み替え潜在需要・顥在化・住宅夕イ プ選択・居住ゾーン選択のプロセスを組み込んだ住宅需 要・立地分析モデル, 土木計画学研究・講演集, No. 10, pp. 259 266, 1987.

25）山田ほか：東京大都市圏における住宅市場の計量分析, 経済企画庁経済研究所, 1976.

26）宮本・宮地：非集計型住宅タイプ選好モデル，都市計画 別冊, pp. 139 144, 1982.

27）林・磯部・富田：非集計手法を用いた住宅需要分析モデ ル, 土木計画学研究・講演集, No. 5, pp. 547 555, 1983.

28）枝村 - 川井・橋本 : 阪神臨海地域における転居世帯の行 動分析について, 土木計画学研究 - 講演集, No. 5, pp. 556 564, 1983.

29) Anas, A. : Dynamic Forecasting of Travel Demand, Residential Location and Land Development, International Symposium on New Directions in Urban Modelling, 1983.

30) Wrigley, N. and Longley, P.A. : Discrete Choice Modelling in Urban Analysis, Geography and Urban Environment Progress in Research and Applications, D. T. Herbert et al. ed., John Wiley \& Sons Ltd., 1984.

31）戸田・天野・西村：居住環境の改善を目的とする住み替 え発生の要因分析, 第 41 回土木学会年次講演会概要集, pp. 159 160, 1986.

32）林・富田：住宅立地の動的予測方法に関する研究, 土木 計画学研究・講演集, No. 9, pp. 115 122, 1986.

33）森杉・大野：地価を内生化した居住地選択モデル, 土木 計画学研究・講演集, No. 8, pp. 453 459, 1986.

34）林・中村・富田：土地利用交通モデルを用いた郊外鉄道 新線の効果分析の試み, 土木計画学研究・講演集, No. 6, pp. 163 170, 1984.

(1988.1.11 · 受付) 